資料

\title{
けい光灯による室内照明の参考データ†
}

\section{柰門会員 小笠原善丸* 正会員 石井重行*}

\section{1. まえがき}

けい光灯に上る室内照明について, 实務家に今日から の参考となるようなきわめて身近な問題で，かつ現在京 でほとんど公表されていないものを数種とり上げ，計算 や実験に基ついて解明し，実用的な参考データとして提 供する。

\section{2. 器具配置と照度分布}

\section{1 方形の室の場合}

ある室の所要平均照度を出すためのランプ本数は, 光 來法で容易に求められるが, 器具の形式, 灯数および配 置によって照度分布は非常に変化する。

このデータは, 拡散カバー付きの埋込みけい光灯器具 で, 一定の面積を一定のランプ数で照明する場合, 各種 の器具配置について, 照度分布を理論計算で求めたもの である.

\subsection{1 計 算 方 法}

計算には次の仮定を設けた。

(a) 光源は等輝度長方形の平面光源とする（一般の抬 散力バー付き埋込みけい光灯器具は, 近似的にこの上う に見なせる配光である).

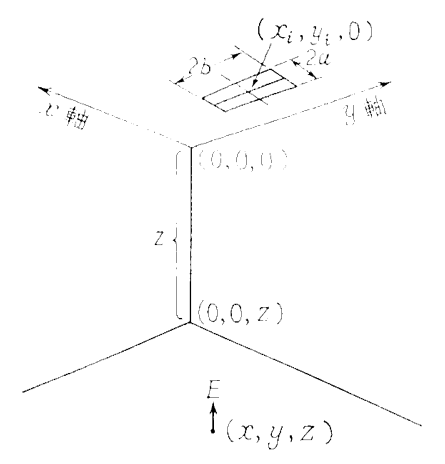

第 1 図 計算点の立体夾槽

$\dagger$ Technical Data on Lighting Design with Fluorescent

* Lamp. (b) 作業面から天井要での高さは $1.65 \mathrm{~m}, 2.15 \mathrm{~m}$, 2,65mの 3 種とする（床面から天州までの高さがそれぞ れ $2.5 \mathrm{~m}, 3 \mathrm{~m}, 3.5 \mathrm{~m}$ 想定した).

(c) 作杽面の広さは，一般のビルなどで多く採られて いる柱間隔の $7 \mathrm{~m} \times 7 \mathrm{~m}$ とした.

使用した計算式は次のとおりである。第1図におい

て光源中心の座僄を $\left(x_{i}, y_{i}\right)$

照度を求める点の坐慓を $(x, y)$

光源の大きさを $2 a \times 2 b$

之すると, 立体角投射の泣則1) から，求める点の水平面 照度 $E$ は

$$
\begin{aligned}
E= & \frac{L}{2 \pi} \sum_{k=1}^{4}\left(\frac{x_{k}}{\sqrt{x_{k}{ }^{2}+Z^{2}}} \tan ^{-1} \frac{y_{k}}{\sqrt{x_{k}{ }^{2}+Z^{2}}}\right. \\
& \left.+\frac{y_{k}}{\sqrt{y_{k}^{2}+Z^{2}}} \tan ^{-1} \frac{x_{k}}{\sqrt{y_{k}^{2}+Z^{2}}}\right)^{2)} \cdots \cdots \cdots \cdots(1)
\end{aligned}
$$

第 1 表

\begin{tabular}{c|c|c}
\hline$K$ & $x_{k}$ & $y_{k}$ \\
\hline 1 & $a+\left(x-x_{i}\right)$ & $b+\left(y-y_{i}\right)$ \\
2 & $a-\left(x-x_{i}\right)$ & $b+\left(y-y_{i}\right)$ \\
3 & $a+\left(x-x_{i}\right)$ & $b-\left(y-y_{i}\right)$ \\
4 & $a-\left(x-x_{i}\right)$ & $b-\left(y-y_{i}\right)$ \\
\hline
\end{tabular}

光源が多い場合には，それぞれの光源についてこの式 で求めた照度を加算する。

上式中の $L$ は光源の光束発散度で, 次の上らな仮定に 上り等めた。

作業面 $7 \mathrm{~m} \times 7 \mathrm{~m}$ につさけ光ランプ FL $40 \mathrm{SW}$ (全 光束 $3,300 \mathrm{~lm}$ ） 24 本优用し，

器具効摔 $\eta=0.5$

保守率 $M=0.63$

とし，下記の場合について計算する。

6 灯用器具（カバー面大きさ $1,200 \mathrm{~mm} \times 1,200 \mathrm{~mm}$ ) 4 古

4 灯用器具（カバー面大きさ $900 \mathrm{~mm} \times 1,200 \mathrm{~mm}$ ) 6 台

3 灯用器具（カバー面大きさ $300 \mathrm{~mm} \times 1,200 \mathrm{~mm}$ ) 8 台 
2 灯用器具（カバー面大きさ $300 \mathrm{~mm} \times 1,200 \mathrm{~mm}$ )

12 台

6 灯用器具の光束発散度は

$$
L=\frac{3,300 \times 6 \times 0.5 \times 0.63}{1.2 \times 1.2} \doteqdot 4,300(\mathrm{rlx})
$$

间様に 4 灯月器具では $L=3,820(\mathrm{rlx})$

3 灯用器具では $L=8,590(\mathrm{rlx})$

2 灯用器尖では $L=5,730(\mathrm{rlx})$

\section{1 .2 照 度 分 布}

室の中心を原点とし， $0.25 \mathrm{~m}$ 䦌隔のこうし（格子） 月の各点について計算した。第 2 図は器具 1 古の場命 の計算䛧，第 3 図は各種の器具配置に上万照度分布図 で作桨面を分制し，各区西作業面から光源までの高さ を変光た場命の照度分布を示した。

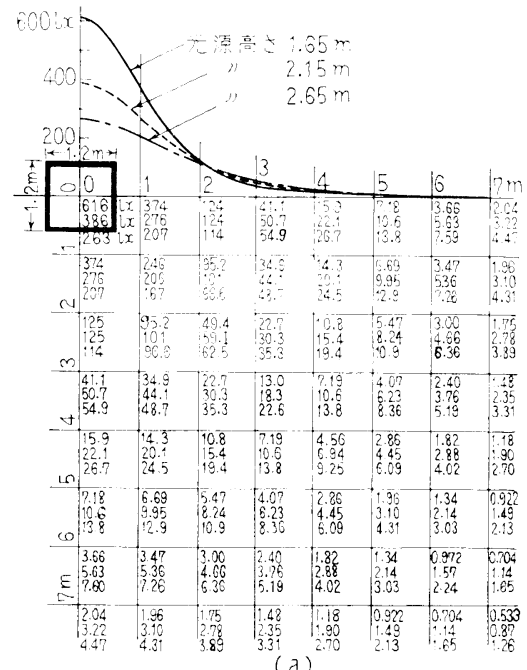

(a)

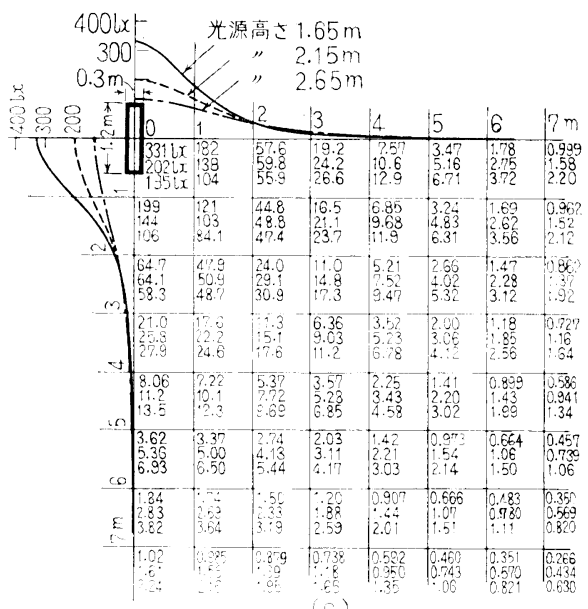

このデータでは, $7 \mathrm{~m} \times 7 \mathrm{~m} 1$ 区画に拈汁る器具配置 と照度分布の関係について示した。夷祭にはこのよらな 区再が隣接してあれば当然それらからの影響があり，ま たこれだけの大きさの独立した案なら，壁面吅らの反射

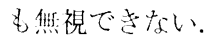

したがってこのデータだけで結論を壮せないが，㽞度 屯らの傾们をつかをためのものである。

\section{2 ライン照明の室の場合}

至内照明で, けい光灯器具を連続して一起间隔で取り 洲けた場介の列間隔，光源高さと照度主らの関係を求め た。これは許される最大の照展もらから，外間隔を沈女 るときの参考資料である。

\section{2.1 計 算 方 法}

計算上の仮定は，前述 2.2.1 の(a)，(b)，(c)および次の

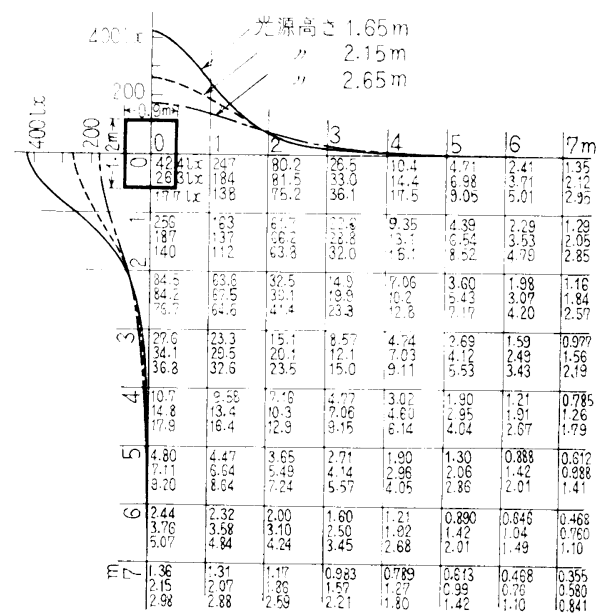

(b)

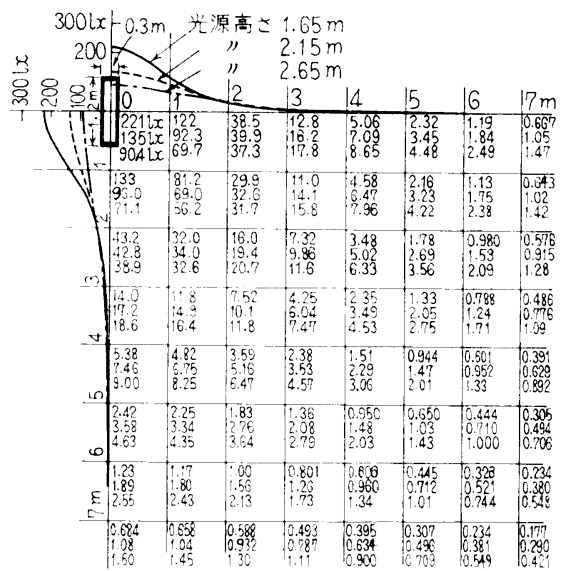

(d)

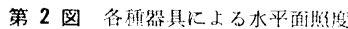

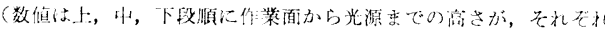
$1.65 \mathrm{~m}, 2.15 \mathrm{~m}, 2.65 \mathrm{~m}$ の埸合を州与。 

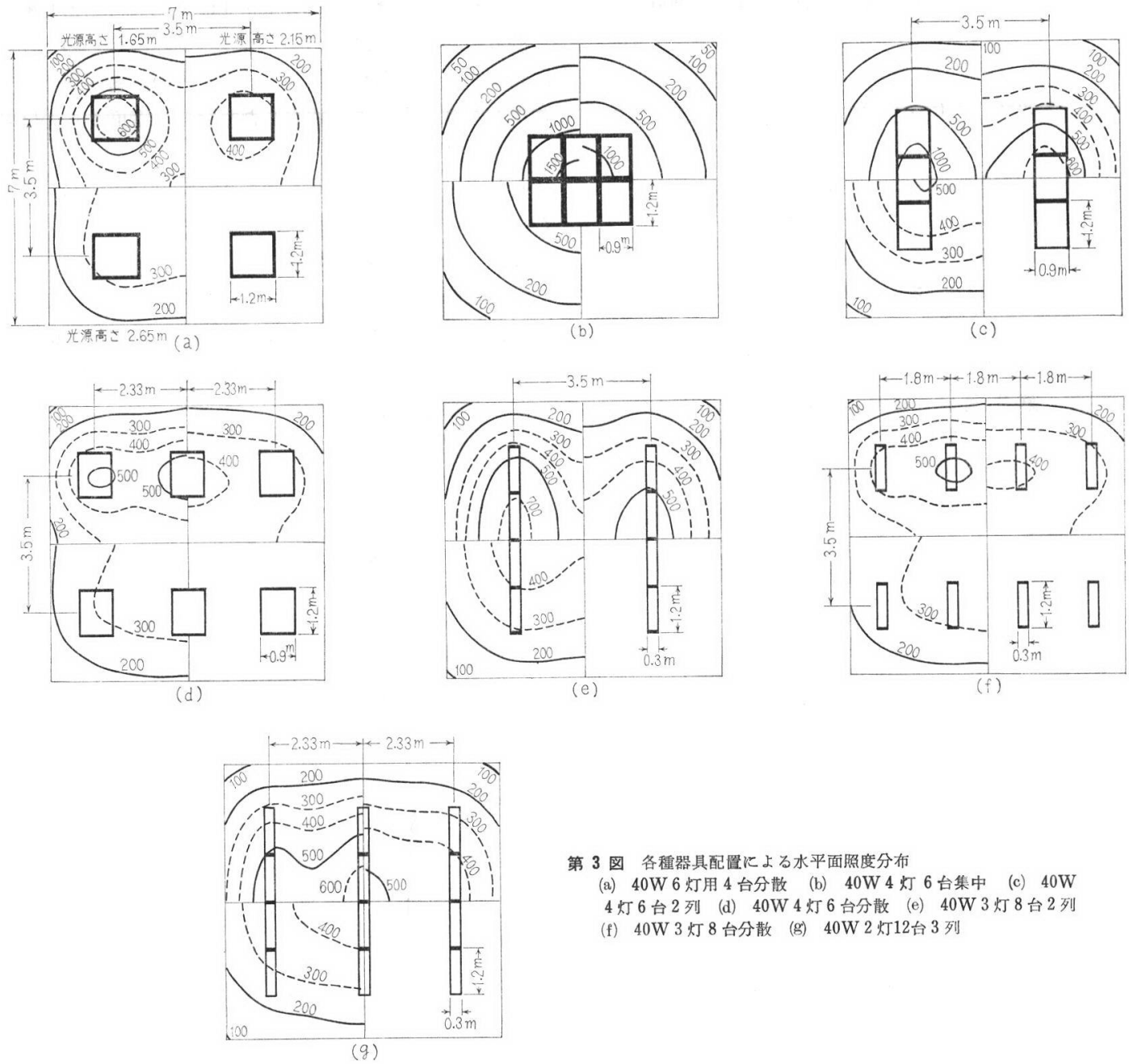

第 3 図 各種器具配置に上る水平面照度分布

(a) $40 \mathrm{~W} 6$ 灯用 4 台分散 (b) $40 \mathrm{~W} 4$ 灯6 台集中 (c) $40 \mathrm{~W}$

4 灯 6 台 2 列 (d) $40 \mathrm{~W} 4$ 灯 6 台分散 (e) $40 \mathrm{~W} 3$ 灯 8 台 2 列

(f) $40 \mathrm{~W} 3$ 灯 8 台分散 (g) $40 \mathrm{~W} 2$ 灯12台 3 列

\section{各項である.}

(a) 光源の列間隔は $3 \mathrm{~m}, 5 \mathrm{~m}, 7 \mathrm{~m}$ の 3 種について 行なら.

(b) 室の大ささ $50 \mathrm{~m} \times 50 \mathrm{~m}$

光源の大きさ $0.3 \mathrm{~m} \times 40 \mathrm{~m}$ ( $40 \mathrm{~W} 2$ 灯用連続器具)

基礎理論式は, 前述 2.2 .1 とほぼ同じなので省略する.

光源面の光束発散度は 2.1 の 2 灯用器具と同じく $L=$

$5,730 \mathrm{rlx}$ とする.

\section{2 .2 照 度 分 布}

室の中心を原点とし， $0.5 \mathrm{~m}$ 間隔のこうし（格子）目 上の各点の照度を計算した。

第 4 図は, 光源が室の中心に一列だけついている場 合の光源と平行方向, および直角方向の室の中心線上の 照度曲線を対数目盛りで示した。 また第 5 図は光源が 等間隔に数列配置されている場合の光源と平行方向, 直 角方向の照度曲線である.

ライン照明は，大規模な事務所，工場などでよく用い

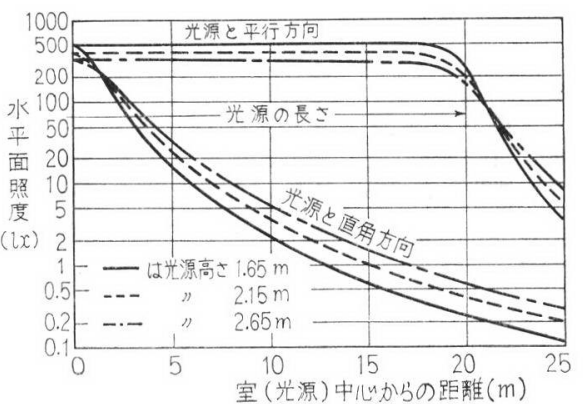

第 4 図 ライン状光源による照度曲線

られている照明方法である，この場合の配置は一般の器 具配置, たとえば器具間隔は光源高さの 1.5 倍以内3)に するなどという通則にあてはめることができないが，適 当な通則は今までなかったようである.

照度むらの許容範囲は,アメリカでは室内照明の場合 (最大一平均)/平均, あるいは(平均一最小)/平均が $30 \%$ 以内なら一様な照明であるといわれている4). このデー 


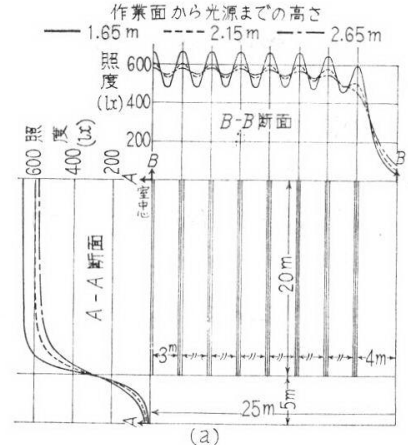

(a)

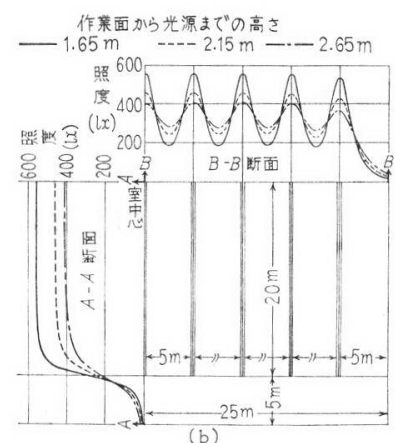

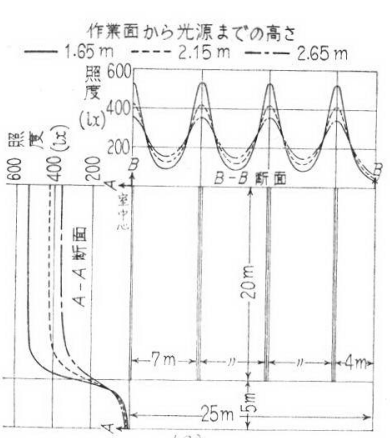

第 5 図 ライン照明による照度曲線 (光束発散度 $5730 \mathrm{Im} / \mathrm{m}^{2}$, 光源の大きさ $0.3 \mathrm{~m} \times 40 \mathrm{~m}$, 室の広さ $50 \mathrm{~m} \times 50 \mathrm{~m}$ )

$\begin{array}{lll}\text { (a) 光源間隔 } 3.0 \mathrm{~m} & \text { (b) 光源間隔 } 5.0 \mathrm{~m} & \text { (c) 光源間隔 } 7.0 \mathrm{~m}\end{array}$

第 2 表 ライン照明の光源高さ, 列問隔と均せい度

\begin{tabular}{|c|c|c|c|c|c|c|}
\hline$\approx$ 列間隔 $(\mathrm{m})$ & 3(平均照 & 度 $5731 \mathrm{x}$ ) & $\begin{array}{l}5 \text { (平均 } \\
\mathrm{lx} \text { ) }\end{array}$ & 照度 344 & $\begin{array}{l}7 \text { (平均) } \\
\mathrm{lx} \text { ) }\end{array}$ & 照度 246 \\
\hline 光源高さ $(\mathrm{m})$ & $\begin{array}{c}\text { 最大照度 } \\
(\mathrm{lx})\end{array} \mid$ & $\begin{array}{c}\text { 均せい度 } \\
(\%)\end{array}$ & $\begin{array}{l}\text { 最大照度 } \\
(1 \mathrm{x})\end{array}$ & 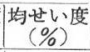 & $\begin{array}{l}\text { 最大照度 } \\
(\mathrm{lx})\end{array}$ & $\begin{array}{c}\text { 均せい度 } \\
(\%)\end{array}$ \\
\hline 1.65 & 665 & 16 & 557 & 62 & 533 & 117 \\
\hline 2.15 & 605 & 6 & 458 & 33 & 422 & 72 \\
\hline 2.65 & 580 & 1 & 404 & 17 & 357 & 45 \\
\hline
\end{tabular}

タで室中心付近の光源列間照度分布から均せい度を計算 すると第 2 表のようになる。計算の基礎となる平均照 度は

\section{光源面の光束発散度 $\times$ 光源の幅} 光源の列間隔

\section{として算出し}

光源間隔 $3 \mathrm{~m}$ の場合 $5731 \mathrm{x}$

$$
\begin{aligned}
& 5 \mathrm{~m} \text { の場合 } 3441 \mathrm{x} \\
& 7 \mathrm{~m} \text { の場合 } 2461 \mathrm{x}
\end{aligned}
$$

照度の屯らはこの場合, 最大値と平均值との差のほう が大きいので(最大一平均)/平均をとった。

\section{3 帯状に器具を配置した場合}

けい光灯照明によるいわゆる局部的全般照明の場合, たとえば, コンベア上だけを重点的に照明するような場 合に, コンベア上の平均照度を光束法で求めることはを ずかしい。

このような場合について，反射がさ付きけい光灯を带 状に配置した次の 2 例を検討した。

(a) 第 6 図のように, 器具を 1 台ずつ並列等間隔に 配置した場合の器具間隔, および取付け高さと列中央の 作業面平均照度との関係.

(b) 第 7 図のように, 器具をライン状に 2 列配置し た場合の列間隔，拉よび取付け高さと列中央の作業面平 均照度との関係.

\subsection{1 計 算 方 法}

計算の条件として

Vol 51 No. 6

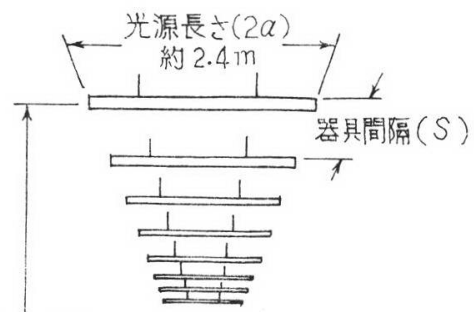

取付宁高志

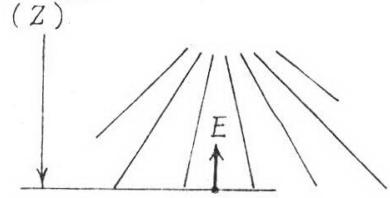

第 6 図 並列等間隔配睓

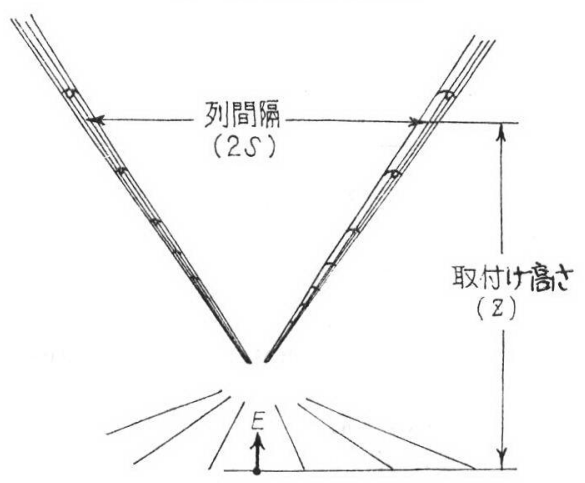

第 7 図 ライン状 2 列配四

(a) 器具は, $110 \mathrm{~W} 1$ 灯用反射がさ付きけい光灯器具 （三菱 F H-11601形）および同 2 灯用（三菱 FH-11602 形)

(b) 保守率は 0.67

とした.

計算式は次のと拈りである.

(a) 並列間隔配置（第 6 図）の場合

光源の大きさを（器具間隔 $\times$ 光源長さ）とし, この大 ささの平面から（器具 1 台あたりのランプ全光束 $\times$ 器具 
效摔）だ卢の光束が一様に出ているものと僘定する, 器 具の配罪が哭限に続くとして，※体所投射の法則を適用 方之列中央の水平面照度は

$$
E=\frac{L \cdot a \cdot M}{\sqrt{Z^{2}}+a^{2}}(\mathrm{~lx})^{*}
$$

L：光束癷散度:

$(\mathrm{rlx})$

$2 a$ : 光源の長已(篫 6 図参照)

$M:$ 保守摔

$Z$ : 取付许高さ

光束発散度は削㲹条件加与

$$
L=\frac{F \cdot y}{2 a \cdot s}
$$

$F ：$ 器具あたりのランプ食光束

$\eta$ : 器具効摔

$S:$ 器具間陷

したガのて

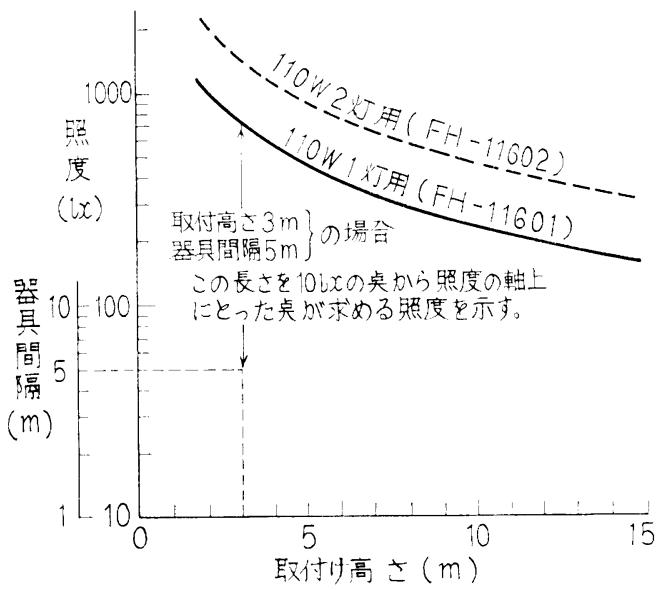

$$
\begin{aligned}
& \text { 第 } 8 \text { 图站列配圈による照度曲線 } \\
& \text { 使用器具：110W1灯扰よび } 2 \text { 灯反射がき付き }
\end{aligned}
$$

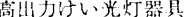

$$
\begin{aligned}
& \text { 储朋シング：FLR } 110 \mathrm{HW} \text { 全光束 } 8,700 \mathrm{Im} \\
& \text { (十⿱亠⿻口丿(子) } \\
& E=\begin{array}{c}
F \cdot \gamma_{i} \cdot M \\
2 S_{\mathrm{V}} / Z^{2}+a^{2}
\end{array} \quad(\mathrm{~lx}
\end{aligned}
$$

1:式から，照度は器具間阔 $S$ に逆比例することがわか る.この関係を対数で表わすと

$\log E=\log \left(\frac{F \cdot \eta \cdot M}{2 \sqrt{Z^{2}+a^{2}}}\right)-\log S$

\footnotetext{
* (1) 式に招いて $x_{i}, y_{i}, x, y=0$ と扰くと

$E=\frac{4 L}{2 \pi} \frac{a}{\sqrt{a^{2}+Z^{2}}} \tan ^{-1} \frac{b}{\sqrt{a^{2}+Z^{2}}}+\frac{b}{\sqrt{b^{2}+Z^{2}}} \tan ^{-1} \frac{a}{\sqrt{ } b^{2}+Z^{2}}$ $b \longrightarrow \infty$ から$$
\tan ^{-1} \underset{\sqrt{a^{2}+Z^{2}}}{\frac{b}{2}} \rightarrow \frac{\pi}{2}, \tan ^{-1} \frac{a}{\sqrt{ } b^{2}+Z^{2}} \longrightarrow 0
$$$$
\therefore \quad E=L \cdot \frac{a}{\sqrt{a^{2}+Z^{2}}}=\frac{L \cdot a}{\sqrt{a^{2}+Z^{2}}}
$$

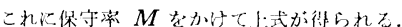

したがって（S=1 m) の埸合の取付忛高さと照度の 阙係をEを刘数目盛りにした片対数グラフで表わすと， 上式を利用して，任意の器具間隔の場命の照度さグラフ から簡単に流又敢ることができる.

第 8 図に例として亩記器具の埸合のグラフを示す。

(b) ライン状 2 列の場合

光源は哭限厓の等輝度 楾光源として積分与ると, 列 中䦌点作柴面の水平而照度は

$$
E=\frac{\pi \cdot B \cdot Z \cdot M}{\left(S^{2}+Z^{2}\right)}
$$

$B \cdots$ 単位辰さあたりの光度 $(\mathrm{cd} / \mathrm{m})$
$Z$ : 取付忖高さ

$2 S:$ 列間院

(m)

$M$ : 保守㳯

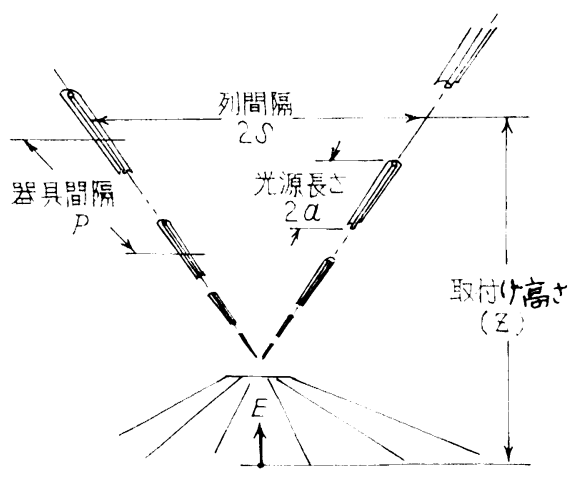

第 9 图 2 夘于点配罣

この場合， $B$ は计い光灯器具ではランプ軸に百角方问 の配光曲線から鉛直角が $\tan ^{-1}(S / Z)$ 方向の光度を読 み，これをランプ長さ（朔記器具の場合約 $2.4 \mathrm{~m}$ ) で制 った值である。

な戈参考路でに器具をライン状にせず，第 9 図のよ らに断続的に配賢する場合，次のようにして平均照度を 求めることができる。

$$
E=\frac{2 \pi \cdot a \cdot B \cdot Z \cdot M}{P\left(S^{2}+Z^{2}\right)}
$$

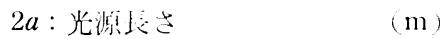

$$
\begin{aligned}
& P: \text { 器具閶霹 (m) }
\end{aligned}
$$

この場合，平均照度とともに均せい度についても十分 考慮する必要がある、器具を千器配置にすることも均せ い度をよくするために効果がある。

\subsection{2 照 度 曲 線}

(3)式により前記器具について計算した結果，列間隔を 一定 ( $3 \mathrm{~m}$ 抢よび $6 \mathrm{~m}$ ) にした埸合の取付け高さと，列 中間点作栄面の水平面照度之の関係海第 10 図，取付计 高さを一定 ( $3 \mathrm{~m}$ 㧍よび $5 \mathrm{~m}$ ) にした場合の列間隔と, 列中間点作業面との関係は第 11 図のようになる. 


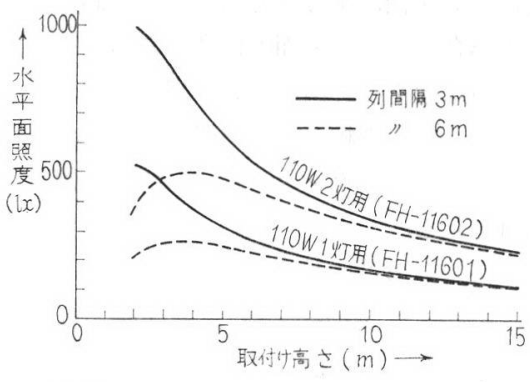

第 10 図 ライン状照明の取付け高さによる 照度曲線

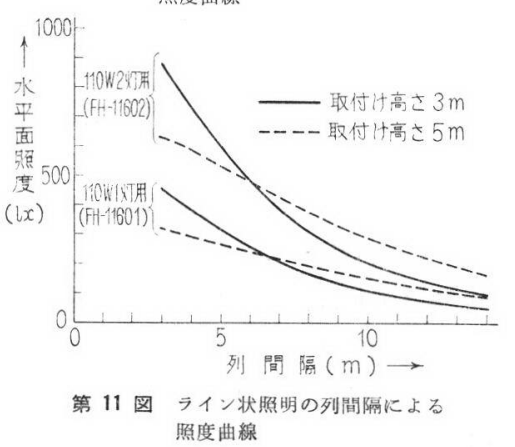

これら 2 例は局部的平均照度を求めたものである. 一 般の平均照度が，平面に打壮る平均を意味しているのに 対し, 上記の例では平面内の特定線上に沶ける平均を求 めた.

なお，並列配置の場合には等輝度面光源として計算し たが，等輝度平面光源に比較してこの種器具の配光はラ ンプ軸に直角方向がふくらみのある形になっているもの が多い。したがって実際の平均照度は計算值より若干上 回るだろら。

ライン状 2 列の場合には, 等輝度線光源として計算し た. この種の器具のランプ軸に平行方向の配光は, 等輝 度線光源の場合と傾向がきわめて似ていることから，大 幅な相違はないものと思われる.

\section{3. 各種埋込み形けい光灯器具の光学特性}

\section{1 各種プラスチックカバー・ルーバによる配光 特性}

最近種々のプラスチックカバーやルーバが，けい光灯 器具に用いられているが, 代表的なもの数種を選んで配 光特性を調べた.

\section{1 .1 供 試 品}

天井埋込及形 $40 \mathrm{~W} 2$ 灯 けい光灯器具 (三菱 F Y-402 形）を用いて実測した。 その断面を第 12 図に示す。ラ ンプは F L $40 \mathrm{~S} \mathrm{~W}(3,300 \mathrm{~lm})$ で供試カバー，ルーバは 次のと接りである.

(a) メタクリル樹脂乳白色半透明平板（アクリライト No. 432) 厚さ $2 \mathrm{~mm}$

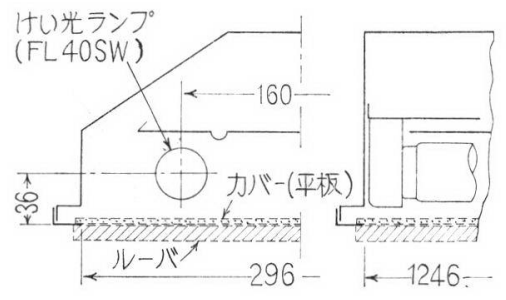

第 12 図 供試けい光灯器具

（b）メタクリル樹脂透明エンボス板（アクリライト・ ダイヤ）(第 13 図 (a) 参照)

(c) ポリスチレン樹脂透明エンボス板（アロンブライ ト S-1104)（第 13 図 (b))

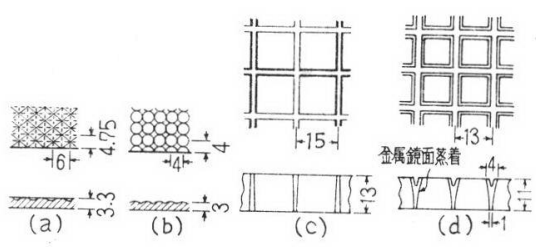

第 13 図 供試カバー,ルーバの形㰡

(a) メタクリル樹脂透明エンボス板

(b) ポリスチレン樹脂透明エンボス板

(c) ポリスチレンルーパ

（d）金属蒸着ルーハ

(d) ポリスチレンルーバ（世界長ルーバ）約 $15 \mathrm{~mm}$ す目の乳白射出成形品（第 13 図 (c) )

(e) 金属蒸着ルーバ（アメリカ製パラウェッジルー バ) 約 $13 \mathrm{~mm}$ ます目のポリスチレン射出成形品で, ルー バの断面が放物面になっており，金属蒸着により鏡面に 仕上げられている（第 13 図(d))

\section{1 .2 光 学 特 性}

第 14 図は，上記カバー,ルーバを使用したときおよ びこれらのない場合の配光曲線である. 乳白半透明メタ クリル樹脂の場合は, ほとんど球状の配光であるのに対 し，他のものはかなり配光が制御されている. 図にはラ ンプ軸を含さ面と，それに直角な面における配光だけを 示した.

な揃記 (a)，(b)，(c) の材料について，いわゆるぺン ざら形に成形したカバーの場合も測定した。 その結果, 配光曲線の形状は平板と同様であったので镪は省略した が, 上方光束が全光束の $1 \sim 2 \%$ あ, 器具直下の光度 が平板の場合の90〜93\%であった.

これらの配光から求めた照明率を第 15 図に示す。比 較しやすいように, 照明率の值の両極端(室指数 $A$ と $J$ ) だけを抽出した。 これを見るとエンボスした透明板が比 較的高い照明率を有し, 高照度を得るために有利である ことがわかる.

次に器具効率, 光度, 輝度について見ると, 第 3 表の とおりである. 器具効率は内蔵されているランプ全光束 

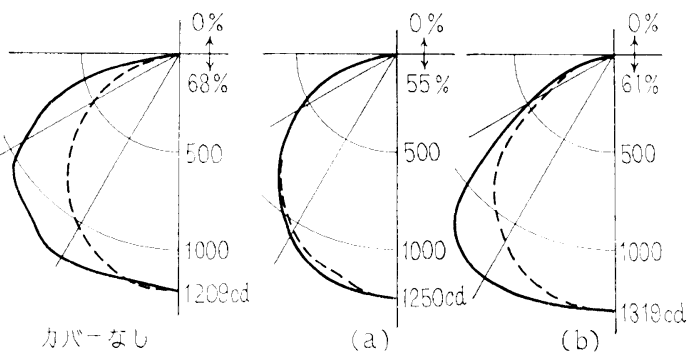

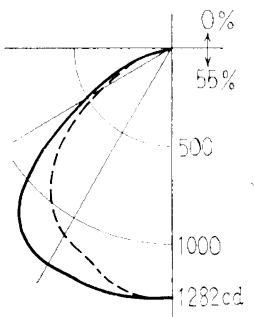

(c)
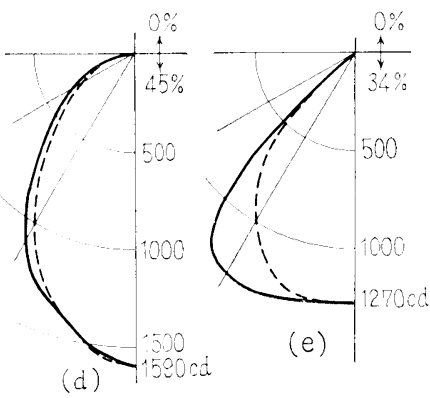

(e)
第 14 図 カ佂別の配光曲螕

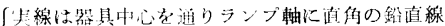
破線は同しくくランブ帆に平行の鉛㨁面配光を示す (a) メタクリ儿娃脂（乳白半透明平板）(b) ×夕

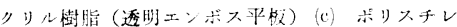

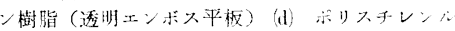

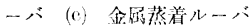

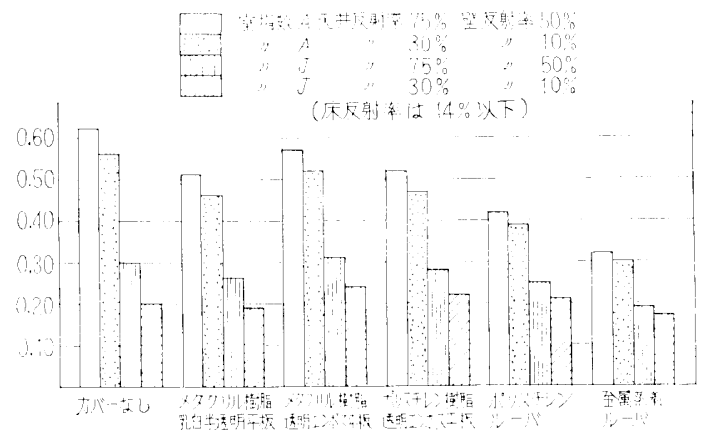

第 15 因 カハー一放の照明率の比較

に対する器具から外治る光束の比である。ガ゙ーなし の場合の器具効率を 100 として他の効信を示寸と, この 器具に批るカバーの総合的な透過辫が求められる.

光度は直下子鉛面们 $45^{\circ}$ 方向の值を示したが，カバー 付きの汪うがいずれる㨁下の光度は高くなっている。
輝度はランプ軸に平行な方向について測定した，カバ 一なしの場合はランプ表面の輝度である.このうち鉛直 角 $75^{\circ}$ の值は通常視野内にはいる輝度であるが, 乳白半 透明メタクリル樹脂板より，透明エンボス板のほうが輝 度が低く，またパラウェッジルーバは０の值を示したこ とは注目される。

照明用カバーの重要な特性として透遇摔とともに最近 とくに委ぶしさの防止一防げん（胘）性一一が採り 上げられてきた。これは通常の視野内にまぶしい光源が あるとき見え方を害したり，目を疲れさせることからで たものである. 天井高さに比べ奥行きの大きい事務室な どでは，鉛泊角 $60^{\circ}$ 以上にはなるべく悉ら゙しい光を出さ ない器具を使用した注らがよい。つ方第 3 表で $60^{\circ}$, $75^{\circ}$ の輝度は低い汪うがよい。いっぽう，効彎はもちろ 儿高い注どよいが效涪がよく，から防壮ん性のあるカバ 一が照明上好委しい材料である。

\section{2 方形埋込み形けい光灯器具の光学特性}

照明の意匠上，最近好んで使われる力形の天非埋达又 卜面拉散カバー付き器具について，その大きさ別による 配光之照明浮之を求めた (第 4 表).

配光は各器具ともき初めて類似的で，その形は鉛直们 の余骇に等しく，かつ水平角によっては注とんど変化が ないので，等辉度面光源として扱っても大略さしつか光 ないことがわかった。

この種の器具では同一カバー材料を使用した場合，一 般汇外形寸法の大きいものが器具効摔が高い。これは器 具内を一つの室と考光て光束法を適用してみると，大き な器具では（ランプ，カバー間の距敞が同じならば）室 指数が大となり，照明率すなわちカバ一面に入射する光 束の相対量が大きくなるためである.

\section{3 各種環状けい光ランプ用埋込み形器具の光学特性}

環状ランプを上下に 2 本組久合わせて，天井埋込み形 器具を作る場合, 效率をよくするため大小の環径のラン ブ，たとえば $30 \mathrm{~W}$ と $40 \mathrm{~W}$ などを組み合わせるが，この 場合にどのような効果があるかを实測により調べた。用 いた器具は下面乳色色半透明メタリリル樹脂（アクリラ イト No. 432) カバーの器具（三罍 FCY-3022 形）で,

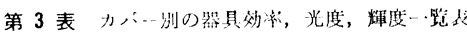

\begin{tabular}{|c|c|c|c|c|c|c|c|c|c|}
\hline$t$ & 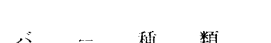 & 器具奻率 & 効事比 & 光 & 度 (cd) & 淔下光度比 & 䊤 & 度 & $(\mathrm{sb})$ \\
\hline (j) & 年 & $(\%)$ & $(\%)$ & 直 & $45^{\circ}$ & $(\%)$ & $45^{\circ}$ & $60^{\circ}$ & $75^{\circ}$ \\
\hline カ & な $し$ & 67.9 & 100 & 1,209 & 1,020 & 100 & 1.11 & 1.01 & 0.74 \\
\hline メタクリ & 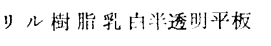 & 54.9 & 81.3 & 1,250 & 843 & 107.0 & 0.38 & 0.37 & 0.31 \\
\hline ×タク & リ几樹脂透明エンボス平板 & 61.1 & 89.9 & 1,319 & 1,055 & 109.1 & 0.43 & 0.30 & 0.20 \\
\hline 叔スチ & レン㰾脂透明エンボス平梑 & 55.3 & 81.3 & 1,282 & 996 & 106.1 & 0.35 & 0.25 & 0.15 \\
\hline 米り & 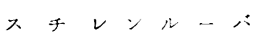 & 45.0 & 66.3 & 1,590 & 622 & 131.5 & 0.23 & 0.18 & 0.14 \\
\hline 金属 & 蒸 着 ル - i & 33.6 & 49.9 & 1,270 & 617 & 105.0 & 0.16 & 0.00 & 0.00 \\
\hline
\end{tabular}


第 4 表 方形埋辽み形乳白ブラスチックカバー付きけい光灯器具の配光曲線・照明济表

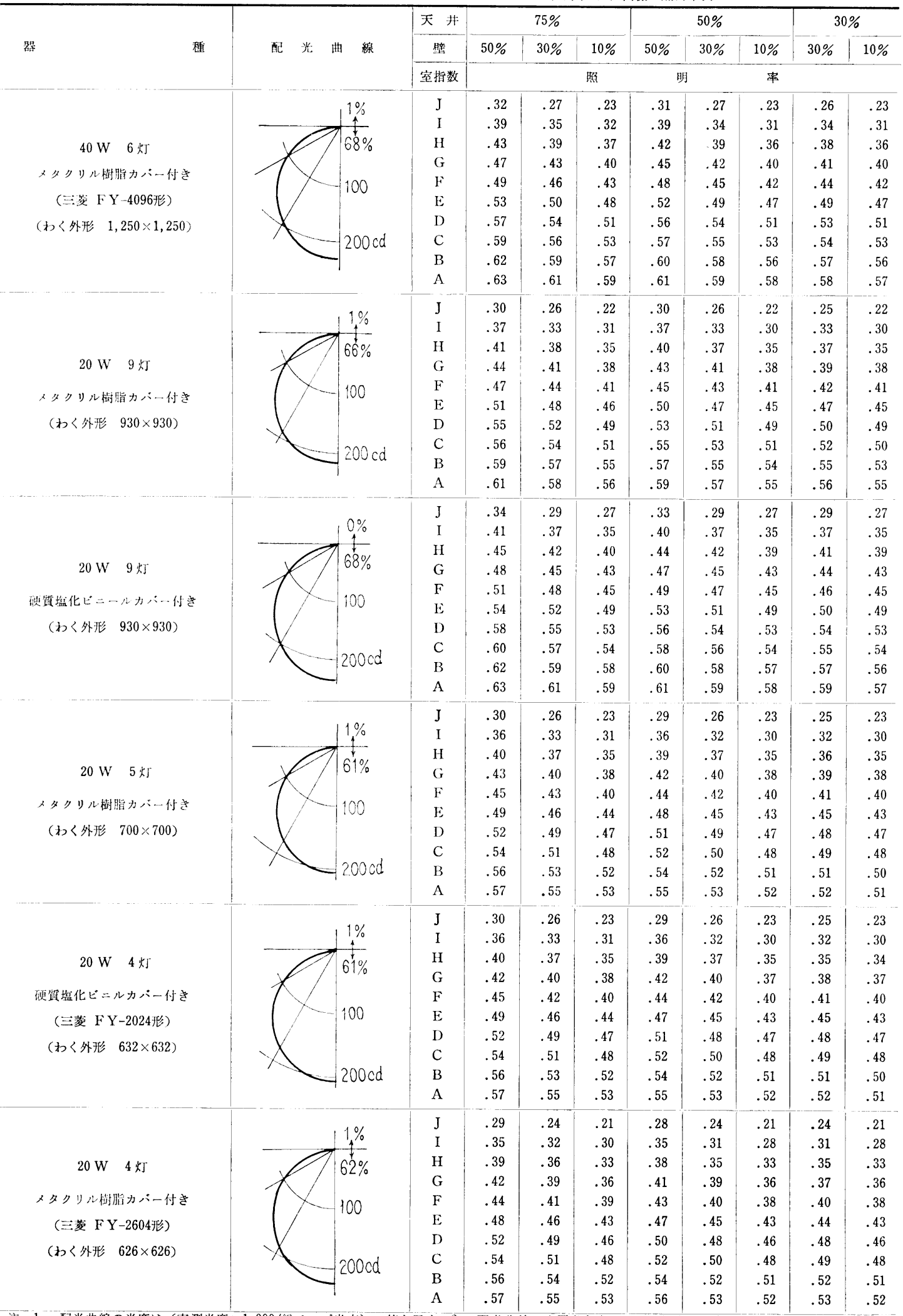

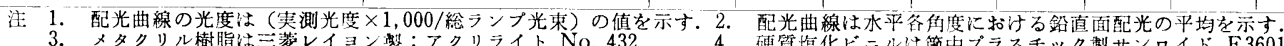


反射板白色メテミ゙塗装

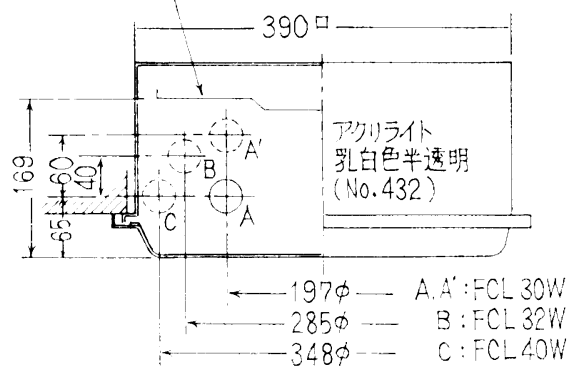

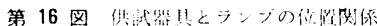

2 はいずれも天井，壁，休などの反射や，他の光源の

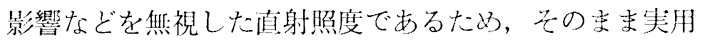
汇供し得ないが, 従来ややも寸机ば単純任光束法汇上り 平均照度を算出し照明設計がなされていたところをこ れに照度分布を考䍐して器具の配置を沈める際に, 広く 灾用できるデータとして劄稿したものである。

また 3 も，照明設計の際に決好器具の作栐につい て，設㖕者の参考になるよう一般的な例について寺とめ たものである。

筆者らは，今後も引き繶きこの種の㙋用的なデータを 求めて行きたいと思っているボ，こ扎らデータの活月

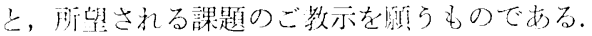

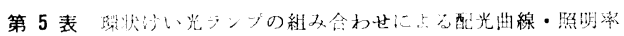

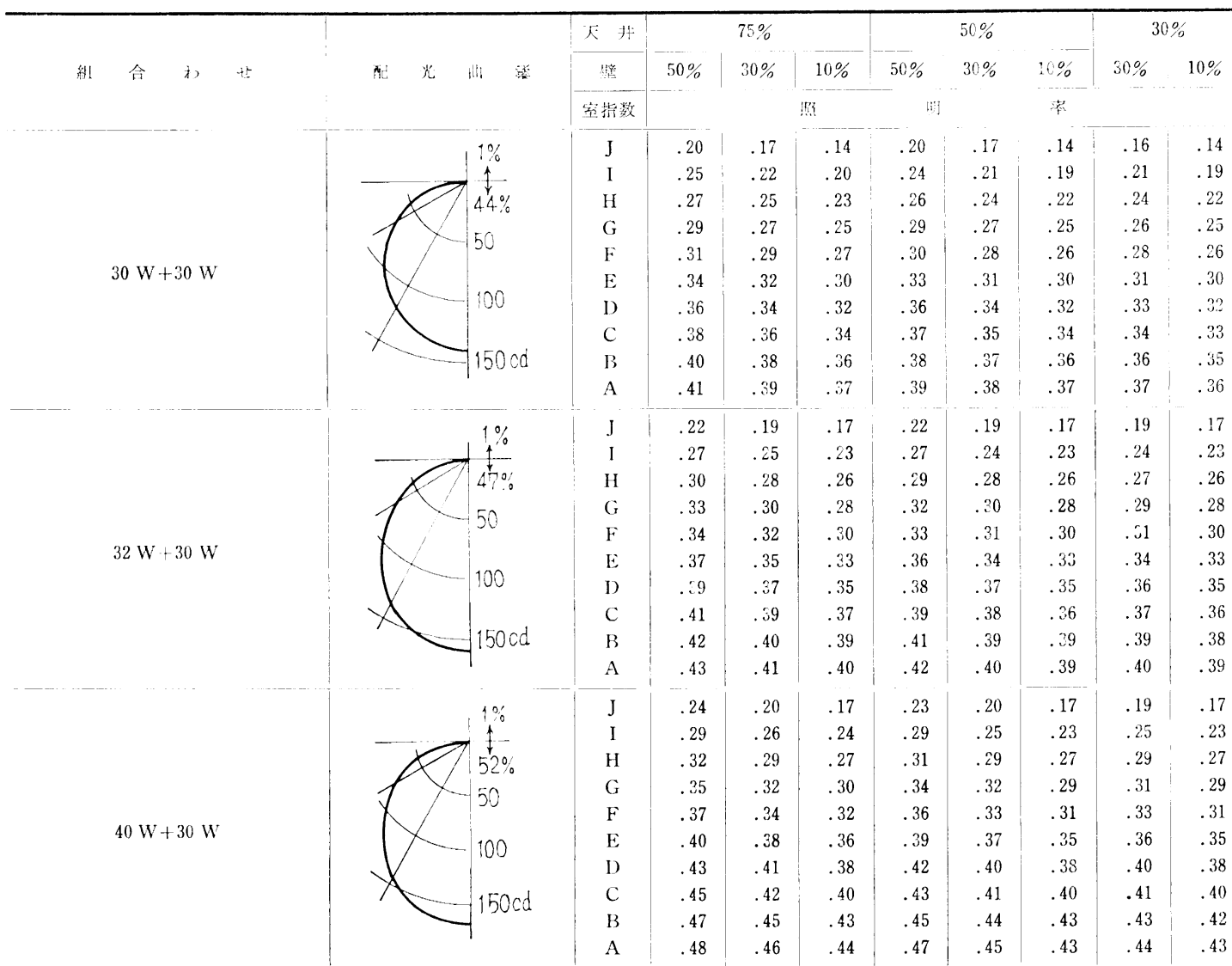

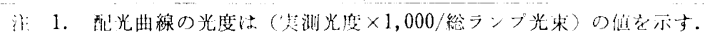

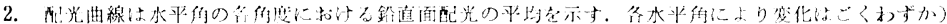

\section{ランフ位谓は第 16 図にハす寸。}

測定の結果は第 5 表に示す。これによれば上下で摆径 の異なったランプを使用少ると同径のランプを使用した 場合より, 1〜2割程度効摔がよくなることが判明した。

\section{4.むすび}

本稿の 2 は電算機を使用して計算したもの，3は実験 により求めたデータである.

\section{考 文 献}

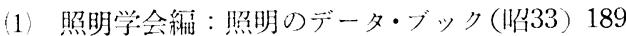

(2) " : " (") 192

(3) " : " " " (") 212

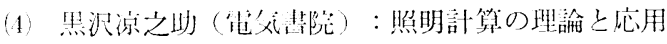
(昭29） 22

（受付 1967年. 月12日 再受付1967年 3 月22日） 